\title{
PENINGKATAN KEMAMPUAN TEKNIK DASAR PASSING PERMAINAN BOLA VOLI MELALUI METODE DRILL
}

\author{
Zaenal Fanani ${ }^{1)}$ \\ 1) SMP NEGERI 2 Trenggalek
}

\begin{abstract}
ABSTRAK: Permasalahan yang dikaji dalam penelitian tindakan kelas ini adalah, bagaimanakah peningkatan kemampuan teknik dasar passing permainan bola voli melalui metode drill di kelas IX A semester 1 tahun pelajaran 2011/2012 di SMP Negeri 2 Trenggalek. Adapun tujuan penelitian ini untuk mendapatkan gambaran mengenai peningkatan peningkatan kemampuan teknik dasar passing permainan bola voli melalui metode drill di kelas VII A semester 1 tahun pelajaran 2011/2012 di SMP Negeri 2 Pogalan. Jenis penelitian ini adalah penelitian tindakan kelas yang dilaksanakan dalam 2 siklus, yang masing-masing siklus terdiri atas tahap perencanaan, tindakan, observasi, dan refleksi. Data yang diperoleh dalam penelitian ini hasil tes performance siklus 1 dan siklus 2. Maka dari hasil tersebut dapat diambil kesimpulan bahwa, dari seluruh pelaksanaan kegiatan tindakan kelas melalui pembelajaran metode drill dapat meningkatkan kemampuan teknik dasar passing permainan bola voli pada siswa kelas VII A semester 1 tahun pelajaran 2011/2012 di SMP Negeri 2 Trenggalek
\end{abstract}

Kata kunci : Teknik Dasar, Metode Drill.

ABSTRACT: The problem studied in this class action research is, how to improve the ability of the basic techniques of passing volleyball through the drill method in class IX A semester 1 of the 2011/2012 school year at SMP Negeri 2 Trenggalek. The purpose of this study is to get an overview of the increase in the ability of the basic technique of passing volleyball through the drill method in class VII A semester 1 of the 2011/2012 school year at SMP Negeri 2 Pogalan. This type of research is classroom action research conducted in 2 cycles, each cycle consisting of planning, action, observation, and reflection. The data obtained in this study are the results of the performance tests for cycle 1 and cycle 2. Then from these results it can be concluded that, from the entire implementation of classroom action activities through learning the drill method can improve the basic technical skills of volleyball passing in class VII A semester 1 students 2011/2012 school year at SMP Negeri 2 Trenggalek

Keywords: Basic Technique, Drill Method.

\section{PENDAHULUAN}

Peneliti sebagai guru mata pelajaran Pendidikan Jasmani dan Olahraga (Penjasorkes) menghadapi permasalahan dalam pembelajaran teknik dasar permainan bola voli. Meskipun hampir semua siswa menyukai permainan bola voli, namun teknik yang digunakan masih belum benar karena mereka belajar secara otodidak (belajar sendiri). Siswa belajar permainan bola voli dirumah, baik di lapangan besar dengan bola karet maupun sekedar bermain di lapangan kecil dengan bola plastik.

Kegemaran bermain bola voli dilingkungan rumah merupakan hal ini sangat positif bagi pembelajaran bola voli di sekolah, mereka banyak yang tertarik dan senang bermain jenis olah raga ini. Namun hal ini juga membawa hal negatif, karena para siswa bermain dengan teknik ala kadarnya, mereka berlatih sendiri tanpa pendamping. Tidak ada yang mengarahkan atau memberi teknik dasar bermain. Mereka sekedar bermain tanpa pola maupun teknik yang benar.

Berbagai upaya telah dilakukan oleh guru untuk meningkatkan kemampuan teknik dasar permainan bola besar yakni Bola Voli, namun sangat sulit untuk membenahi teknik 
dasar bermain siswa khususnya di kelas IX A semester 1 tahun pelajaran 2011/2012. Metode yang dipakai guru selama ini adalah metode konvensional dimana peran guru masih sangat mendominasi pembelajaran dan tidak memanfaatkan sumber belajar dan media pembelajaran yang lebih variatif. Hal ini disebabkan oleh keterbatasan waktu, sarana dan prasarana yang kurang mendukung, dan keterbatasan pengetahuan guru untuk merancang pembelajaran yang menarik.

Pada pembelajaran sebelum penelitian khususnya pada kompetensi dasar mempraktikkan variasi dan kombinasi teknik dasar salah satu permainan dan olahraga beregu bola besar lanjutan dengan koordinasi yang baikserta nilai kerjasama, toleransi, percaya diri, keberanian, menghargai lawan, bersedia berbagi tempat dan peralatan. Materi yang dipilih guru adalah permainan bola voli terutama teknik passingtangan atas dan passingtangan bawah. Siswa kesulitan mempraktikkan cara passing yang benar, mereka asal saja memukul bola tanpa memperhatikan awalan atau bahkan mereka melanggar garis yang telah ditentukan.

Pada pembelajaran indikator awal KD yakni memahami bentuk-bentuk passing bola voliguru memberi penilaian langsung pada praktik kinerja dengan 4 kategori, awalan, sikap tubuh, perkenaan bola, dan hasil. Guru membukukan hasilnya, terlihat hasil nilai praktik siswa masih sangat rendah yaitu nilai rata-rata 63,75 dari 24 siswa dengan prosentase ketuntasan klasikal sebesar 54,17\%.Melihat hal ini sangat mendesak dan penting bagi peneliti untuk segera melaksanakan penelitian tindakan kelas untuk meningkatkan kemampuan dalam pembelajaran khususnya di kelas IX A semester 1 tahun pelajaran 2011/2012 di SMP Negeri 2 Trenggalek

Dalam permainan bola voli dikenal berbagai teknik dasar, antara lain passing, passing, smash, dan blok. Dan untuk dapat bermain bola voli harus betul-betul dikuasai dahulu teknik-teknik dasar tersebut. Penguasaan teknik dasar secara sempurna dapat dicapai dengan melakukan latihan-latihan kontinyu dan menggunakan metode latihan yang baik. Untuk membangkitkan kemampuan siswa, perlu adanya metode mengajar yang baru. Guru yakin dengan metode yang tepat dan menarik akan membuat siswa antusias dan semangat untuk meningkatkan kemampuan dalam mengikuti pembelajaran sehingga kualitas pembelajaran akan meningkat. Untuk dapat meningkatkan kemampuan seluruh siswa maka perlu metode yang benar-benar baik danmenyenangkan sehingga dapat membenahi teknik dasar siswa dalam permainan bola voli.

Passing bola voli adalah tindakan yang dilakukan untuk mengawali atau memulai suatu permainan olahraga bola voli. Dalam olahraga bola voli passing juga merupakan serangan awal, oleh karena itu setiap pemain yang melakukan passing akan berusaha untuk membuat bola passing yang mematikan lawan, seperti laju bola cepat, keras, mengarah pada daerah yang kosong, mengarah pada pemain yang lemah, tidak begitu menguasai passing atau sebagainya. Bola passing yang dilakukan dengan sangat baik dan mematikan memang sangat penting untuk dilakukan dalam mengawali permainan, selain bisa mematikan lawan dan mendapat poin/ nilai secara langsung, bola passing tersebut bisa membuat pihak lawan kesulitan untuk mengembalikan bola ataupun menyusun serangan dengan sempurna.

Metode pembelajaran yang dapat meningkatkan kemampuan passing atas dan passing bawah adalah pembelajaran dengan metode drill.Metode drilladalah latihan dengan praktek yang dilakukan berulang kali secara kontinyuuntuk mendapatkan keterampilan dan ketangkasan praktis tentangpengetahuan yang dipelajari. Dari segi 
pelaksanaannya siswa terlebih dahulutelah dibekali dengan pengetahuan secara teori. Kemudian dengan tetapdibimbing oleh guru, siswa diminta mempraktikkannya sehingga menjadimahir dan terampil.

Metode drill memiliki kelebihan yakni dapat mengkokohkan daya ingatan murid, karena seluruh pikiran, perasaan, kemauan dikonsentrasikan pada pelajaran yang dilatihkan, siswa dapat menggunakan daya fikirnya dengan baik, dengan pengajaran yang baik, maka siswa menjadi lebih teliti,serta adanya pengawasan, bimbingan dan koreksi yang segera serta langsung dari guru.

Berdasarkan permasalahan dan pernyataan di atas, akan dilakukan Penelitian Tindakan Kelas yang berjudul "Peningkatan Kemampuan Teknik Dasar Passing Permainan Bola Voli Melalui Metode Drill di Kelas IX A Semester 1 Tahun Pelajaran 2011/2012 di SMP Negeri 2 Trenggalek".

Permasalahan yang dikaji dalam penelitian tindakan kelas ini dapat dirumuskan sebagai berikut. Bagaimanakah peningkatan kemampuan teknik dasar passing permainan bola voli melalui metode dril ldi kelas IX A semester 1 tahun pelajaran 2011/2012 di SMP Negeri 2 Trenggalek? Sehingga penelitian ini bertujuan ini untuk mendapatkan gambaran mengenai peningkatan peningkatan kemampuan teknik dasar passing permainan bola voli melalui metode drill di kelas IX A semester 1 tahun pelajaran 2011/2012 di SMP Negeri 2 Trenggalek

Dengan adanya penelitian tindakan di kelas IX A Semester 1 Tahun Pelajaran 2011/2012 di SMP Negeri 2 Trenggalek memberikan manfaat yang besar:

1. Bagi siswa, penelitian ini dapat meningkatan kemampuan siswa dalam teknik dasar passing permainan bola voli pada mata pelajaran Penjasorkes, sehingga akan memicu peningkatan prestasi mata pelajaran lain secara umum.

2. Bagi sekolah, penelitian ini dapat meningkatkan mutu pembelajaran dan memperkaya variasi pembelajaran melalui metode drill di SMP Negeri 2 Trenggalek.

3. Bagi guru, penelitian melalui teknik pemodelan ini dapat meningkatkan profesionalisme guru sehingga guru semakin terpacu dalam meningkatkan kemampuan siswa.

\section{KAJIAN PUSTAKA}

Siswa SMP merupakan individu-individu yang sedang tumbuh dan berkembang dalam rangka pencapaian kepribadian yang dewasa. Pertumbuhan individu terlihat pada bertambahnya aspek fisik yang bersifat kuantitatif serta bertambahnya aspek psikis yang lebih bersifat kaulitatif. Dalam kegiatan pendidikan dan pembelajaran, keduanya dilayani secara seimbang, selaras dan serasi agar dapat terbentuknya kepribadian yang integral. Adapun kegiatan ini dilaksanakan tidak lain untuk menghasilkan siswa dengan berbagai kemampuan yang dapat dihandalkan nanti ketika mereka turun pada konsep nyata yakni berkarya di dalam kehidupan masyarakat.

Donald (Sardiman, 2009:73-74) mengemukakan kemampuan adalah perubahan energi dalam diri seseorang yang ditandai dengan munculnya pikiran dan didahului dengan tanggapan terhadap adanya tujuan. Menurut Hamalik (2008:162) kemampuan dapat dibagi menjadi dua jenis yaitu sebagai berikut: (1) Kemampuan intrinsik, adalah kemampuan yang tercakup di dalam situasi belajar dan menemui kebutuhan dan tujuantujuan murid. (2) Kemampuan ekstrinsik, adalah kemampuan yang hidup dalam diri siswa dan berguna dalam situasi belajar yang fungsional. 
Poerwadarminta (2007: 742) mempunyai pendapat lain tentang kemampuan yaitu mampu artinya kuasa (bisa, sanggup) melakukan sesuatu, sedangkan kemampuan artinya kesanggupan, kecakapan, kekuatan. Pendapat lain dikemukakan juga oleh Nurhasnah (2007: 552) bahwa mampu artinya (bisa, sanggup) melakukan sesuatu, sedangkan kemampuan artinya kesanggupan, kecakapan. Sehubungan dengan hal tersebut Tuminto (2007: 423) menyatakan bahwa kemampuan adalah kesanggupan, kecakapan atau kekuatan. Demikian pula apabila seseorang dapat melakukan sesuatu dengan benar tetapi lambat, juga tidak dapat dikatakan mampu. Seseorang yang mampu dalam suatu bidang tidak ragu-ragu melakukan pekerjaan tersebut, seakan-akan tidak pernah dipikirkan lagi bagaimana melaksanakannya, tidak ada lagi kesulitankesulitan yang menghambat.

Menurut Hamalik (2008:162) kemampuan dapat dibagi menjadi dua jenis yaitu sebagai berikut: (1) Kemampuan intrinsik adalah kemampuan yang tercakup di dalam situasi belajar dan menemui kebutuhan dan tujuan-tujuan siswa. (2) Kemampuan ekstrinsik adalah kemampuan yang hidup dalam diri siswa dan berguna dalam situasi belajar yang fungsional. Menurut Uno (2007:23) hakikat kemampuan belajar adalah dorongan internal dan eksternal pada siswa-siswa yang sedang belajar untuk mengadakan perubahan tingkah laku, pada umumnya dengan beberapa indikator atau unsur yang mendukung. Hal itu mempunyai peranan besar dalam keberhasilan seseorang dalam belajar. Dari beberapa pengertian kemampuan diatas, maka dapat disimpulkan bahwa kemampuan adalah kompetensi mendasar yang perlu dimiliki siswa yang mempelajari lingkup materi dalam suatu mata pelajaran pada jenjang tertentu. Dalam penelitian ini yang dimaksud dengan kemampuan siswa adalah kompetensi mendasar yang perlu dimiliki siswa yang diukur melalui tes kinerja terutama dalam teknik dasar passing pada permainan bola voli.

Metode Drill merupakan kesatuan yang teratur dalam latihan. Menurut Suharno (1980: 2) metode drill (metode latihan siap) merupakan metode yang lazim dipergunakan untuk menguasai gerakan-gerakan secara otomatis untuk mencapai kecakapan, keterampilan sesuatu cabang olahraga.

Nana Sudjana, berpendapat bahwa metode drill adalah suatu cara mengajar dimana siswa melaksanakan kegiatan-kegiatan latihan agar memiliki ketangkasan atau keterampilan yang lebih tinggi dari apa yang dipelajari. Metode drill adalah suatu kegiatan melakukan hal yang sama, berulang-ulang secara sungguh-sungguh dengan tujuan untuk memperkuat suatu asosiasi atau menyempurnakan suatu keterampilan agar menjadi bersifat permanen (Nana Sudjana, 1991).

Sugiyanto (1993: 372) mengatakan bahwa hal yang perlu dipertimbangkan apabila menggunakan metode drill yaitu: (1) Drill digunakan sampai gerakan yang benar bisa dilakukan secara otomatis 10 atau menjadi terbiasa, serta menekankan pada keadaan tertentu gerakan itu harus dilakukan. (2) Siswa diarahkan agar berkonsentrasi pada kebenaran pelaksanaan gerakan serta ketepatan penggunaannya. (3) Selama pelaksanaan drill perlu selalu mengoreksi agar perhatian tetap tertuju pada kebenaran gerak. (4) Pelaksanaan drill disesuaikan dengan bagian-bagian dari situasi permainan olahraga yang sebenarnya. Hal ini bisa menimbulkan daya tarik dalam latihan. (5) Perlu dilakukan latihan peralihan dari situasi drill ke situasi permainan yang sebenarnya. (6) Suasana kompetitf perlu diciptakan dalam pelaksanaan drill, tetapi tetap ada kontrol kebenaran geraknya. 
Metode drill merupakan metode pembelajaran yang menekankan pada penguasaan teknik suatu cabang olahraga yang dalam pelaksanaanya dilakukan secara berulangulang, (Sugiyanto, 1993:371) menyatakan, dalam metode drill siswa melakukan gerakangerakan sesuai dengan apa yang diinstruksikan guru dan melakukannya secara berulangulang. Latihan berulang-ulang gerakan ini dimaksudkan agar terjadi otomatisasi gerakan. Oleh karena itu, dalam metode drill perlu disusun tata urutan pembelajaran yang baik agar siswa terlibat aktif, sehingga akan diperoleh kemampuan yang optimal. Keaktifan siswa melakukan tugas ajar sangat dituntut dalam metode konvensional. Kelangsungan proses latihan pada tahap berikutnya ialah penguasaan teknik yang ideal. Hal ini tergantung pada inisiatif dan self-activity dari pihak siswa itu sendiri. Sedangkan guru bertugas mengarahkan penguasaan gerak, melakukan koreksi dan evaluasi setiap terjadi kesalahan teknik adalah penting terhindar dari pola gerakan yang salah dari teknik yang dipelajari. Seperti dikemukakan Sugiyanto (1993: 372) bahwa, setiap pelaksanaan drill perlu selalu mengoreksi agar perhatian tertuju pada kebenaran gerak

Ciri yang khas dari metode drill adalah kegiatan berupa pengulangan yang berkalikali dari suatu hal yang sama. Bentuk-bentuk metode drill dapat direalisasikan dalam berbagai bentuk teknik, antara lain teknik Inquiry (kerja kelompok), Discovery (penemuan), Micro Teaching, Modul Belajar, dan Belajar Mandiri (Nana Sudjana, 1991).

Penerapan metode drill dalam pembelajaran pendidikan olah raga, khususnya mengenai passing atas dan passing bawah pada materi bola voli sebagai berikut:

1) Siswa terlebih dahulu dibekali dengan pengetahuan secara teori, sesuai dengan bahan ajaran yang akan diterapkan dengan metode pembelajaran $d r i l l$, dalam hal ini berarti teori mendalam mengenai passing dalam bola voli.

2) Guru memberikan contoh praktik sebelum diberikannya latihan tentang materi pembelajaran yang telah diberikan.

3) Siswa dibagi menjadi dua kelompok besar untuk saling berpasangan, jika yang kelompok pertama melakukan praktik passing, kelompok lainnya menunggu bola di seberang net.

4) Siswa melaksanakan praktik sesuai dengan teori yang telah diberikan.

5) Guru mengoreksi danmembetulkankesalahan-kesalahan latihan yang dilakukan oleh siswa.

6) Siswa diharuskan mengulang kembali latihan untuk mencapai gerakan otomatis yang benar.

Dalam pengulangan yang keempat kalinya dengan teknik yang bervariasi, guru melakukan evaluasi kemampuan siswa, dengan rubrik penilaian yang telah ditentukan, sebagai bahan pengkajian peningkatan kemampuan siswa.

\section{METODE PENELITIAN}

\section{Rancangan Penelitian}

Penelitian ini menggunakan rancangan PenelitianTindakan Kelas (PTK). Menurut Suharsimi Arikunto (2007: 3), penelitian tindakan kelas merupakan suatu pencermatan terhadap kegiatan belajar berupa sebuah tindakan, yang sengaja dimunculkan dan terjadi dalam sebuah kelas secara bersama. PTK mempunyai tujuan untuk memperbaiki dan meningkatkan layanan profesional guru sebagai pendidik dalam menangani proses pembelajaran di kelas. 
Penelitian ini bermaksud untuk mengatasi suatu permasalahan di dalam pembelajaran, yaitu kurangnya kemampuan siswa dalam mata pelajaran Penjasorkes pada kemampuan teknik dasar passing permainan bola voli di kelasIX A SMP Negeri 2 Trenggalek Tahun Pelajaran 2011/2012 melalui metode drill. Alur PTK yang digunakan pada penelitian ini adalah PTK model Kemmis dan Taggart. Menurut Endang Mulyatiningsih (2009:71), Kemmis danTaggart membagi prosedur penelitian tindakan dalam empat tahap yaitu perencanaan, tindakan dan observasi, refleksi. Penjelasan empat langkah tersebut adalah sebagai berikut:

\section{Perencanaan (Planning)}

Tahap perencanaan kegiatan yang dilakukan antara lain: identifikasi masalah, perumusan masalah dan analisis penyebab masalah, dan pengembangan intervensi. Tindakan perencanaan yang dilakukan oleh penelitiyaitu merencanakan perangkat pembelajaran, rencana penyusunan alat perekam data, dan merencanakan pelaksanaan pembelajaran dengan menggunakan pembelajaran metode drill. Guru harus benar-benar merancang dengan teliti detail skenario pembelajaran karena merupakan metode baru yang diharapkan dapat meningkatkan kemampuan belajar siswa. Setelah itu guru menyusundan menyiapkan perangkat permainan, dan apa saja yang mungkin diperlukan dalam proses pembelajaran. Guru juga merancangkelompoksiswa untuk bekerja sama dalam komunitas belajar dalam mencapai tujuan yang sama yakni meningkatkan kemampuan teknik dasar passing atas dan passing bawah di kelas IX A SMP Negeri 2 Trenggalek semester 1 tahun pelajaran 2011/2012melalui metode drill.

\section{Tindakan}

Kegiatan tindakan dilaksanakan sesuai dengan skenario yang telah dibuat dan perangkat yang telah disiapkan. Sesuai materi teknik dasar passing atas dan passing bawah, guru membagi indikator menjadi 2 yakni siklus 1, teknik dasar passing atas, dan siklus 2, teknik dasar passing bawah. Kegiatan tiap pertemuan yang akan dilaksanakan selama 2 siklus tiap siklus berlangsung 2 kali pertemuan pada intinya dijabarkan sebagai berikut:

\section{Pertemuan Pertama}

1) Siswa terlebih dahulu dibekali dengan pengetahuan secara teori, sesuai dengan bahan ajaran yang akan diterapkan dengan metode pembelajaran drill, dalam hal ini berarti teori mendalam mengenai passing dalam bola voli.

2) Guru memberikan contoh praktik sebelum diberikannya latihan tentang materi pembelajaran yang telah diberikan.

3) Siswa dibagi menjadi dua kelompok besar untuk saling berpasangan, jika yang kelompok pertama melakukan praktik passing, kelompok lainnya menunggu bola di seberang net.

4) Siswa melaksanakan praktik sesuai dengan teori yang telah diberikan, semua siswa harus melakukan sebanyak 4 kali pengulangan secara bergantian, dalam pelaksanaannya guru akan menghentikan sejenak pengulanganbeberapa kali, untuk memberikan tambahan teori maupun pembenahan-pembanahan gerakan sehingga didapatkan hasil yang maksimal.

5) Guru mengoreksi dan membetulkan kesalahan-kesalahanl atihan yang dilakukan oleh siswa.

Pertemuan Kedua 
1) Siswa kembali dibagi menjadi 2 kelompok besar sedangkan guru ada ditengah kedua kelompok untuk memberikan umpan pada tiap individu siswa.

2) Siswa diharuskan mengulang kembali latihan untuk mencapai gerakan otomatis yang benar.

3) Pengulangan yang ketiga kalinya atau terakhir, guru melakukan evaluasi kemampuan siswa, dengan lembar tes. Evaluasi dilakukan pada saat melakukan kegiatan yang ketiga kalinya.

\section{Observasi}

Kegiatan observasi dilaksanakan untuk mengamati proses tindakan dan dampak dari pemberian tindakan. Guru dibantu kolaborator melakukan observasi pada saat pelaksanaan tindakan dalam penelitian untuk mengamatiperubahan tingkah laku siswa agar hasil dari pengamatan didapat hasil yang lebih rinci dan detail.

Dalam pengamatannya kolaborator mengisi lembar observasi proses pembelajaran mengenai aktivitas siswa sehingga dapat digambarkan bagaimana kemajuan kemampuan siswa dalam kompetensi teknik dasar passing atas dan passing bawah kemudian dikonsultasikan dengan peneliti untuk menentukan peningkatan setiap siklusnya.

\section{Refleksi}

Refleksi merupakan kegiatan mengulas secara kritis tentang perubahan yang terjadi pada siswa, suasana kelas, dan guru. Pada tahap ini, peneliti menjawab pertanyaan mengapa dilakukan penelitian, bagaimana melakukan penelitian, dan seberapa jauh intervensi telah menghasilkan perubahan secara signifikan. Tahap ini peneliti melakukan analisis dan refleksi terhadap permasalahan dan hambatan yang dihadapi di lapangan.

Pelaksanaanpenelitianini, dilakukansecarakolaborasiantarapenelitidengan guru serumpun di sekolah. Adapunpelaksanaantiapsiklusselama 2 x 40 menit ( 2 jam pelajaran).

\section{Subjek Penelitian}

Penelitian tindakan kelas ini dilaksanakan Guru Bidang Studi Penjasorkes kelas IX A, ZAENAL FANANI, S.Pd. di SMP Negeri 2 Trenggalek semester 1 tahun pelajaran 2011/2012 dengan didampingi oleh Bapak Mochammad Ghofar sebagai Kolaborator. Pelaksanaan penelitian ini di kelas IX A SMP Negeri 2 Trenggalek, Kabupaten Trenggalek, semester 1 Tahun Pelajaran 2011/2012. SMP Negeri 2 Trenggalek merupakan salah satu sekolah menengah pertama yang beralamatkan di Jalan Mastrip desa Parakan Kecamatan Trenggalek Kelas IX A dipilih peneliti karena kelas tersebut diajar oleh peneliti, dan di kelas tersebut peneliti mendapatkan permasalahan kurangnya kemampuan siswa dalam bidang Penjasorkes. Adapun jumlah seluruh siswa adalah 24 siswa. Terdiri dari 17 siswa laki-laki dan 7 siswa perempuan.

Penjadwalan penelitian sesuai dengan perencanaan program tahunan dan program semester mata pelajaran Penjasorkes Kelas IX A SMP Negeri 2 Trenggalek semester 1 Tahun Pelajaran 2011/2012 yakni pada materi passing bola voli mulai bulan Agustus 2011 hingga bulan September 2011.

\section{Instrumen Penelitian}

Menurut Suharsimi Arikunto (2007: 203), instrumen penelitian dapat diartikan sebagai alat atau fasilitas yang digunakanoleh peneliti dalam mengumpulkan data agar 
pekerjaannya lebih mudah danhasilnya lebih baik, dalam arti lebih cermat, lengkap, dan sistematis, sehingga data yang diperoleh mudah untuk diolah.

Instrumen dalam penelitian ini dipakai oleh peneliti untuk mengamati responden, sehingga diperoleh informasi yang dibutuhkan dalam penelitian. Untuk mengetahui peningkatan kemampuan siswa dibutuhkan instrumentes. Metode tes ini merupakan tes performance (tes unjuk kerja).

Metode tes unjuk kerja yang digunakan dalam penelitian ini adalah untuk mengukur sejauhmana peningkatan kemampuan siswa dalam melaksanakan teknik dasar bermain bola voli yakni passing atas dan passing bawah. Metode tes terbagi menjadi 2 yakni tes siklus 1 siswa melaksanakan tes unjuk kerja passing atas, dan tes siklus 2, siswa melaksanakan tes unjuk kerja passing bawah.

\section{TeknikPengumpulan Data}

Dari hasilpelaksanaanpenelitiantindakan, ditentukanteknikpengumpulan data yaitu cara-cara yang digunakanolehpenelitiuntukmengumpulkan data. Pengambilan data dilakukanmetode tes melalui tes siklus 1 dan tes siklus 2 .

\section{Tes Siklus 1}

Tes ini dilaksanakan pada saat pengulangan yang ketigakalinya atau terakhir pada metode drill. Dengan lembar penilaian, siswa dievaluasi pada saat melakukan kegiatan yang ketigakalinya pada Siklus 1, dengan melihat dengan 4 kategori, awalan, sikap tubuh, perkenaan bola, dan hasil. Dalam tes ini siswa melaksanakan praktik passing atas dengan berbagai teknik yang telah diajarkan.

\section{Tes Siklus 2}

Tes siklus 2 dilaksanakan sebagaimana siklus 1 setelah berlangsungnya proses pembelajaran, dengan lembar penilaian, siswa dievaluasipadasaatmelakukankegiatan yang ketigakalinya pada Siklus 2, dengan melihat dengan 4 kategori, awalan, sikap tubuh, perkenaan bola, dan hasil. Dalam tes ini siswa melaksanakan praktik passing bawah dengan berbagai teknik yang telah diajarkan.

\section{TeknikAnalisis Data} berikut:

Langkah-langkah yang dilakukan peneliti dalam menganalisis data adalah sebagai

1) Menetapkan Pedoman Penilaian Tes Siklus 1 dan 2

Data perolehan tes siswa dipaparkan secara deskriptif untuk mengetahui peningkatan kemampuan siswa dalam teknik dasar bermain bola voli. Data skor siswa dari awalan, sikap tubuh, perkenaan dengan bola dan hasil ditentukan sebagai berikut:

Selanjutnya skor dikonversikan menjadi nilai. Untuk mengubah skor menjadi nilai maka dilakukan konversi skor kedalam nilai atau $z$ skor yaitu nilai yang berskala $1-100$ (Anas Sudijono, 2003:313) dengan menggunakan rumus konversi sebagai berikut:

$$
\mathrm{NA}=\frac{\sum \mathrm{S}}{\sum \mathrm{SM}} \mathrm{X} 100
$$

Keterangan :

NA =Nilai akhir

$\sum \mathrm{S} \quad=$ Jumlah Skor Siswa 
$\sum \mathrm{SM}=$ Jumlah skor ideal (skor maksimal)

$100=$ Standar nilai ideal.

\section{HASIL DAN PEMBAHASAN}

\section{Hasil Penelitian \\ Kegiatan dan Hasil Pelaksanaan Siklus 1}

Sebelum pelaksanaan kegiatan pembelajaran Siklus 1, peneliti didampingi kolaborator merancang Rencana Pembelajaran (RPP) Siklus 1 pada materi teknik dasar passing atas dan passing bawah dengan menggunakan metode drill. Guru merancang dengan teliti detail skenario pembelajaran yang dapat meningkatkan kemampuan belajar. Setelah itu guru menyusun dan menyiapkan perangkat permainan, dan apa saja yang mungkin diperlukan dalam proses pembelajaran.

Sesuai yang telah direncanakan, pada hari Rabu tanggal 20 September 2011, dengan alokasi waktu 2 jam pelajaran jam pertama hingga kedua, dilaksanakanlah siklus 1. Peneliti mempersilakan kolaborator untuk melaksanakan pengamatan. Siswa sudah bersiap dengan pakaian olah raga mereka di lapangan sekolah. Pada hari itu sejumlah 24 siswa hadir dengan baik.

Kegiatan pembelajaran dimulai dengan rutinitas salam dan do'a.Siswa menjawab serempak dengan baik, pada hari itu semua siswa hadir. Kemudian guru membimbing siswa untuk melakukan pemanasan dan perenggangan otot, hal ini setiap awal pembelajaran praktik olah raga dilakukan untuk mencegah cedera yang fatal.

Setelah melakukan warming up siswa memulai pembelajaran dengan teknik baru untuk melakukan passing atas, dengan teknik yang benar. Guru memberikan contoh passing atas dengan nyata, siswa diberi kesempatan memperhatikan. Beberapa kali guru melakukannya sehingga ada gambaran siswa untuk menirukan dalam latihan-latihan (drill) yang akan dilaksanakannya dengan 4 kali variasi. Drill 1, siswa dibagi kelompokkelompok untuk melakukan passsing atas tanpa net di luar lapangan voli, drill 2 siswa melakukan di bawah net dalam satu regu, drill 3 melewati net, sedangkan drill 4 dilakukan pada pertemuan kedua sebagai bahan penilaian, langkah-langkah pembelajaran yang dilakukan yakni:

7) Siswa melaksanakan praktik sesuai dengan teori yang telah diberikan, drill 1, siswa dibagi kelompok-kelompok untuk melakukan passsing atas tanpa net di luar lapangan voli, semua siswa mendapatkan giliran yang merata;

8) Selanjutnya pada waktu drill 2 siswa diajak guru untuk masuk ke lapangan bola voli untuk melakukan passing atas di bawah net dalam satu regu;

9) Pelaksanaan drill 3 yakni siswa dibagi menjadi regu-regu yang saling berhadapan, dan melakukan passing atas bola voli melewati net.

10) Setelah pengulangan passing atas (drill) dilakukan semua siswa, guru membetulkan kesalahan-kesalahan latihan yang dilakukan oleh siswa.

Dengan pemberian evaluasi dan penguatan materi pada pertemuan pertama siklus 1, guru menutup kegiatan dengan memberikan kesimpulan secara umum, beberapa kekurangan dalam proses pembelajaran dianalisa untuk perbaikan pertemuan selanjutnya. Guru melakukan tindak lanjut dengan memberikan tugas belajar kegiatan passing atas dirumah untuk persiapan pertemuan selanjutnya. Sebagai akhir pembelajaran, guru menutup dengan doa. 
Siklus 1 pertemuan 2 sesuai jadwal yang telah dibuat dilaksanakan hari Rabu tanggal 14 September 2011 di lapangan sekolah. Sebagaimana pertemuan sebelumnya, guru mengucapkan salam, memeriksa kehadiran siswa dan meminta siswa berdo'a. Setelah melakukan pemanasan dan perenggangan otot, sebagai langkahawal penelitian guru kembali mengingatkan kompetensi yang akan dicapai yakni mengenai teknik dasar passing atas dengan koordinasi yang baik.

Setelah mengawali pembelajaran, guru meminta siswa menuju ke lapangan bola voli untuk melakukan drill 4, pengulangan kali ini menjadi dasar penilaian yang direkap oleh guru/ peneliti, pelaksaannya sebagai berikut:

1. Siswa dibagi menjadi 2 regu, regu A dan regu B, regu A yang mendapatkan giliran pertama melakukan passing atas sedangkan regu B menunggu diseberang net.

2. Secara bergantian giliran regu B melakukan passing atas bola voli, regu A menunggu diseberang net.

3. Dalam pelaksanaan drill 4, guru memberikan penilaian sebagai data evaluasi kemampuan belajar siswa.

Pada akhir kegiatan, dari24 siswa guru merekap hasil semua rekaman nilai siswa sebagai data peningkatan kemampuan passing atas, ada beberapa siswa yang masih sulit melaksanakan passing atas dengan benar, namun sebagian besar sudah mengalami perkembangan terbukti dengan nilai hasil tes performance yang dilakukan hasilnya jauh lebih baik pra siklus.

Dengan melakukan praktik berkali-kali melalui metode drill, siswa dapat meningkatkan kemampuan karena dapat memperbaiki kesalahan-kesalahan secara berulang-ulang. Selanjutnya guru menutup pembelajaran dengan berdo'a bersama, siswa kembali kekelas untuk berganti pakaian dan belajar materi selanjutnya.

Kegiatan observasi dilaksanakan untuk mengamati proses tindakan dan dampak dari pemberian tindakan. Guru dibantu kolaborator melakukan observasi pada saat pelaksanaan tindakan dalam penelitian untuk mengamati perubahan tingkah laku siswa agar hasil dari pengamatan didapat hasil yang lebih rinci.

Hasil tes performance siklus 1 dengan melihat dengan 4 kategori, awalan, sikap tubuh, perkenaan bola, dan hasil dianalisis dan didiskripsikan untuk menggambarkan peningkatan kemampuan unjuk kerja siswa. Hasil analisa dan pengamatan oleh Kolaborator kemudian diinformasikan pada peneliti agar pembelajaran semakin baik.Kegiatan pengamatan difokuskan pada kegiatan inti dalam RPP. Semua instrumen dan hasil kerja pertemuan pertama atau siklus 1 tertuang dalam halaman lampiran.

Refleksi merupakan kegiatan mengulas secara kritis tentang perubahan yang terjadi pada siswa, suasana pembelajaran, dan guru. Pada tahap ini, peneliti melakukan analisis dan refleksi terhadap permasalahan dan hambatan yang dihadapi di lapangan.

Dari beberapa temuan pada Siklus 1, telah terlihat perkembangan kemampuan passing atas siswa SMP Negeri 2 Trenggalek kelas IX A semester 2 Tahun Pelajaran 2011/2012 namun masih ada beberapa kekurangan, dari diskusi dengan Bapak Mochammad Ghofar, S.Pd, sebagai kolaborator, peneliti memutuskan tindakan perlu dilanjutkan pada Siklus 2.

Hasil tes performancepada Siklus1 diambil dari hasil pengulangan ketiga metode drillSiklus1dengan melihat dengan 4 kategori, awalan, sikap tubuh, perkenaan bola, dan hasil. Pada saat siswa melakukan unjuk kerja, setiap siswa secara individual dievaluasi 
dengan lembar penilaian yang telah dipersiapkan.Hasil tes padaSiklus1 dapat dalam tabel 4.1 berikut ini.

Tabel 4. Tabel Rekapitulasi Hasil Tes performance Siklus 1

\begin{tabular}{|c|c|c|c|c|c|}
\hline No & Rentang & $\mathbf{F}$ & Persentase & Nilai & Kategori \\
\hline 1 & $90-100$ & 0 & $0,00 \%$ & 0 & Tuntas \\
\hline 2 & $80-89$ & 2 & $8,33 \%$ & 160 & Tuntas \\
\hline 2 & $70-79$ & 14 & $58,33 \%$ & 1025 & Tuntas \\
\hline 3 & $60-69$ & 7 & $29,17 \%$ & 445 & Tidak Tuntas \\
\hline 4 & $50-59$ & 1 & $4,17 \%$ & 55 & Tidak Tuntas \\
\hline 5 & $0-49$ & 0 & $0,00 \%$ & 0 & Tidak Tuntas \\
\hline & Jumlah & 24 & $100,00 \%$ & 1685 & \\
\hline & $\begin{array}{r}\mathbf{K} \\
\text { Ket }\end{array}$ & $\begin{array}{l}\text { i-ra } \\
\text { ntas } \\
\text { tun }\end{array}$ & & $\begin{array}{c}70,21 \\
66,67 \% \\
33,33 \%\end{array}$ & \\
\hline
\end{tabular}

Setelah dilakukan analisis data hasil tes unjuk kerjaSiklus 1 diperoleh hasil dari sejumlah 24 siswa, pada rentang nilai 70-100,dicapai 16 siswa atau sebanyak 66,67\% masuk kategori tuntas, sedangkan padarentang nilai 0-69, dicapai oleh 8 siswa atau 33,33\% masuk kategori tidak tuntas. Nilai ini sudah meningkat namun masih belum memenuhi target ketuntasan sebesar 70\%. Dari jumlah seluruh skor perolehan siswa 1.685, maka rata-rata kelas 70,21.Nilai rata-rata tersebut sudah memenuhi KKM sebesar 70 dan mengalami peningkatan dari pratindakan 63,75 menjadi 70,21 pada Siklus1. Dengan demikian masih perlu peningkatan untuk mendapatkan hasil tes unjuk kerja yang lebih baik dengan melanjutkan penelitianSiklus2.

\section{Kegiatan dan Hasil Pelaksanaan Siklus 2}

Perencanaan ulang dilaksanakan dengan memperbaiki semua kekuranganberdasarkan refleksi siklus 1. Dalam siklus 2 pokok bahasan yang diajarkan melanjutkan materi teknik dasar bermain bola voli dengan indikator yang berbeda yakni mempelajari teknik dasar passing bawah. Pada siklus 2 guru merancang Rencana Pembelajaran dengan metode drillpada materi teknik dasar passing bawah, dengan perbaikan yang diperlukan.Guru harusmemberikan petunjuk, arahan, dan contoh yang lebih jelas dan nyata, guru juga harus memperhatikan kesulitanyang dihadapai siswa dalam menelaah teori yang diberikan. Kemudian guru menyiapkan perangkat pembelajaran dan permainan bola voli.

Pada hari Rabu tanggal 21 September 2011, dengan alokasi waktu 2 jam pelajaran, peneliti melanjutkan pelaksanaan penelitian siklus 2. Penelitimenyiapkan alat/media permainan bola volidan sumber belajar lain yang diperlukan untuk kegiatan pembelajaran. Semua siswa berkumpul di lapangan sekolah dengan tertib. Kegiatan pembelajaran dimulai dengan rutinitas salam dan do'a, Siswa menjawab serempak dan berdoa dengan baik, dari sejumlah 24 siswa, semua siswa pada hari itu hadir. Sebagaimana biasa, guru membimbing siswa untuk melakukan pemanasan atau perenggangan otot terlebih dahulu untuk menghindari cedera.

Guru tidak hanya memberikan teori, namun juga memberi contoh nyata pengulangan agar siswa dapat melihat dengan baik.Dalam pelaksanaan drill passsing bawah bola voli dilaksanakan dengan dengan 4 kali variasi. Drill 1, siswa dibagi kelompok-kelompok untuk melakukan passsing bawah tanpa net di luar lapangan voli, 
drill 2 siswa melakukan di bawah net dalam satu regu, drill 3 melewati net, sedangkan drill 4 dilakukan pada pertemuan kedua sebagai bahan penilaian, langkah-langkah pembelajaran yang dilakukan yakni:

1. Siswa melaksanakan praktik sesuai dengan teori yang telah diberikan, drill 1 , siswa dibagi kelompok-kelompok untuk melakukan passsing bawah tanpa net di luar lapangan voli, semua siswa mendapatkan giliran yang merata;

2. Selanjutnya pada waktu drill 2 siswa diajak guru untuk masuk ke lapangan bola voli untuk melakukan passingbawah di bawah net dalam satu regu;

3. Pelaksanaan drill 3 yakni siswa dibagi menjadi regu-regu yang saling berhadapan, dan melakukan passingbawah bola voli melewati net.

4. Setelah pengulangan passingbawah (drill) dilakukan semua siswa, guru membetulkan kesalahan-kesalahan latihan yang dilakukan oleh siswa.

Setelah pengulangan passingbawah dilakukan semua siswa, guru membetulkan kesalahan-kesalahan latihan yang dilakukan oleh siswa. Pada akhir pertemuan pertama siklus 2, guru menutup kegiatan dengan memberikan kesimpulan secara umum, beberapa kekurangan dalam proses pembelajaran dianalisa untuk perbaikan pertemuan selanjutnya. Guru melakukan tindak lanjut dengan memberikan tugas belajar kegiatan passingbawahuntuk persiapan pertemuan selanjutnya. Sebagai akhir pembelajaran, guru menutup dengan doa.

Siklus 2 pertemuan 2 sesuai jadwal yang telah dibuat dilaksanakan hari Rabu tanggal 28 September 2011.Sebagaimana pertemuan sebelumnya, guru mengucapkan salam, memeriksa kehadiran siswa dan meminta siswa berdo'a. Setelah melakukan pemanasan dan perenggangan otot, sebagai langkahawal penelitian guru kembali mengingatkan kompetensi yang akan dicapai yakni mengenai teknik dasar passingbawah dengan koordinasi yang baik.Setelah mengawali pembelajaran, guru meminta siswa menuju ke lapangan bola voli untuk melakukan drill 4passing bawah bola voli, pengulangan kali ini menjadi dasar penilaian yang direkap oleh guru/ peneliti, pelaksaannya sebagai berikut:

1. Siswa dibagi menjadi 2 regu, regu A dan regu B, regu A yang mendapatkan giliran pertama melakukan passing bawah sedangkan regu $\mathrm{B}$ menunggu diseberang net.

2. Secara bergantian giliran regu B melakukan passingbawah bola voli, regu A menunggu diseberang net.

3. Dalam pelaksanaan drill 4passing bawah bola voli, guru memberikan penilaian sebagai data evaluasi kemampuan belajar siswa.

Pada akhir kegiatan pembelajaran, guru merekap hasil semua rekaman nilai siswa sebagai data peningkatan kemampuan passingbawah. Selanjutnya guru menutup pembelajaran dengan berdo'a bersama, siswa kembali kekelas untuk berganti pakaian dan belajar materi selanjutnya.

Selama pembelajaran berlangsung, proses kegiatan belajar siswa diamati oleh kolaborator untuk mengetahui permasalahan dan hambatan peningkatan kemampuan belajar. Hasil pengamatan kemudian didiskusikan oleh guru dan kolaborator. Hasil akhir Siklus 2 dianalisis untuk mengetahui peningkatan kemampuan belajar dalam proses pembelajaran pada materi passing bawah. Kegiatan pengamatan difokuskan pada kegiatan inti dalam RPP. Semua instrumen dan hasil kerja siklus 2 tertuang dalam halaman lampiran 10 hingga lampiran 16 penelitian ini.

Dari paparan data hasil nilai tes siklus 2 menunjukkan penguasaan teknik passing 
bawah, tampak bahwa yang memiliki tingkat nilai melampaui KKM jauh meningkat dari siklus 1, ini berarti kemampuan belajar pada siklus 2 sudah semakin meningkat dibanding siklus 1 dan penelitian ini dikatakan berhasilkarena tingkat penguasaan secara klasikal sudah sangat terpenuhi.

Hasil tes pada Siklus2 diambil dari hasil tes yang dikerjakan siswa pada akhir Siklus2 mengenai passing bawah bola voli. Hasil tes Siklus2 dapat dilihat pada tabelrentang ketuntasan berikut ini.

Tabel 2. Tabel Rekapitulasi Hasil TesUnjuk Performance Siklus2

\begin{tabular}{|c|c|c|c|c|c|}
\hline No & Rentang & $\mathbf{F}$ & Persentase & Nilai & Kategori \\
\hline 1 & $90-100$ & 1 & $4,17 \%$ & 95 & Tuntas \\
\hline 2 & $80-89$ & 8 & $33,33 \%$ & 660 & Tuntas \\
\hline 2 & $70-79$ & 11 & $45,83 \%$ & 805 & Tuntas \\
\hline 3 & $60-69$ & 4 & $16,67 \%$ & 260 & Tidak Tuntas \\
\hline 4 & $50-59$ & 0 & $0,00 \%$ & 0 & Tidak Tuntas \\
\hline 5 & $0-49$ & 0 & $0,00 \%$ & 0 & Tidak Tuntas \\
\hline & Jumlah & 24 & $100,00 \%$ & 1820 & \\
\hline & \multicolumn{3}{|c|}{$\begin{array}{c}\text { Rata-rata } \\
\text { Ketuntasan } \\
\text { Ketidaktuntasan }\end{array}$} & $\begin{array}{c}75,83 \\
83,33 \% \\
16,67 \%\end{array}$ & \\
\hline
\end{tabular}

Setelah dilakukan analisis data hasil tes unjuk kerja Siklus 1 diperoleh hasil dari sejumlah 24 siswa, pada rentang nilai 70-100, dicapai 20 siswa atau sebanyak 83,33\% masuk kategori tuntas, sedangkan pada rentang nilai 0-69, dicapai oleh 4 siswa atau $16,67 \%$ masuk kategori tidak tuntas. Nilai ini sudah meningkat dan sudah memenuhi target ketuntasan sebesar $70 \%$.

Dari jumlah seluruh skor perolehan siswa 1.820, maka rata-rata kelas didapatkan sebesar 75,83. Nilai rata-rata tersebut sudah melampaui KKM sebesar 70 dan mengalami peningkatan dari siklus 170,21 menjadi75,83 pada Siklus 2. Dengan demikian penelitian tindakan kelas IX A semester 1 tahun pelajaran 2011/207 di SMP Negeri 2 Trenggalek telah berhasil.

\section{PEMBAHASAN}

Hasil akhir dari tindakan kelas ini adalah meningkatnya teknik dasar passing atas dan passing bawah dalam permainan bola voli mata di kelas IX A semester 1 tahun pelajaran 2011/2012 SMP Negeri 2 Trenggalek melalui teknik pembelajaran drill. Peningkatan kemampuan belajar tersebut dapat dijabarkan dalam pembahasan berikut ini. Setelah dilakukan kegiatan pada Siklus1 dan Siklus2 ternyata ada peningkatan hasil tes performance atau unjuk kerjadan telah mencapai indikator yang telah ditetapkan sebagaiberikut:

Tabel 3. Perbandingan Hasil Tes Individu Siswa

\begin{tabular}{|c|c|c|c|c|c|c|}
\hline \multirow{2}{*}{ No } & \multirow{2}{*}{ Siklus } & \multicolumn{4}{|c|}{ Rentang Nilai } & \multirow{2}{*}{ Rata-Rata } \\
\cline { 3 - 6 } & & \multicolumn{2}{|c|}{$\mathbf{7 0 - 1 0 0}$} & \multicolumn{2}{|c|}{$\mathbf{0 - 6 9}$} & $\mathbf{6 3 , 7 5}$ \\
\hline 1. & Pra Siklus & 13 & $54,17 \%$ & 11 & $45,83 \%$ & $\mathbf{7 0 , 2 1}$ \\
\hline 2. & Siklus 1 & 16 & $66,67 \%$ & 8 & $33,43 \%$ & $\mathbf{7 5 , 8 3}$ \\
\cline { 3 - 6 } 3. & Siklus 2 & 20 & $83,33 \%$ & 4 & $16,67 \%$ & \\
\hline
\end{tabular}


Dari data hasil penelitian tindakandi Kelas IX A Semester 1 Tahun Pelajaran 2011/2012 di SMP Negeri 2 Trenggalek membuktikan bahwa melalui metode drill dapat meningkatkan kemampuan teknik dasar passing permainan bola voli, terbukti dari datadata padapra siklus, pencapaian nilai rata-rata siswa sebesar 63,75 kemudian siklus 1 nilai rata-rata meningkat sebesar 70,21 selanjutnya pada siklus 2 meningkat lagi menjadi sebesar 75,83. Angka ini sudah melampaui Kriteria Ketuntasan Minimal (KKM) yang ditetapkan sebesar 70 .

Sedangkan prosentase ketuntasan klasikal juga meningkat dari $54,17 \%$ pada pra siklus menjadi $66,67 \%$ pada siklus 1 kemudian meningkat lagi menjadi 83,33\% pada siklus 2. Prosentase ini sudah melampaui target prosentase ketuntasan yang ditetapkan dalam penelitian ini yakni 70\% dari seluruh siswa kelas IX A semester 1 tahun pelajaran 2011/2012 di SMP Negeri 2 Trenggalek.

\section{KESIMPULAN DAN SARAN}

\section{Kesimpulan}

Kesimpulan dari penelitian ini adalah dari seluruh pelaksanaan kegiatan tindakan kelas melalui pembelajaran metode drill dapat meningkatkan kemampuan teknik dasar passing permainan bola voli pada siswa kelas IX A semester 1 tahun pelajaran 2011/2012 di SMP Negeri 2 Trenggalek

\section{Saran}

Berdasarkan pengalaman selama melaksanakan penelitian tindakan kelas di kelas IX A semester 1 tahun pelajaran 2011/2012 di SMP Negeri 2 Trenggalek, maka peneliti memberi saran-saran sebaga iberikut:

1. Guru Penjasorkes diharapkan dapat meningkatkan kemampuan teknik dasar passing permainan bola voli melalui pembelajaran metode drill.

2. Siswa dalam belajar teknik dasar passing bola voli perlu dilatih sesering mungkin agar selalu berkembang lebih baik sehingga mendapatkan prestasi yang lebih tinggi.

3. Berdasarkan hasil penelitian, pembelajaran melalui model pembelajaran metode drill disarankan untuk dikembangkan lebih jauh lagi.

\section{DAFTAR RUJUKAN}

A.M Sardiman. 2009. Interaksi dan Motivas iBelajar-Mengajar. Ed.1. Jakarta: PT Raja GrafindoPersada.

Ahmadi,Nuril. 2007. Panduan olahraga Bola Voli. Solo: Era Pustaka Utama.

Anas Sudijono. 2003.Pengantar Evaluasi Pendidikan. Jakarta, PT. Raja Grafindo Persada, Cet. XII.

Arikunto, Suharsimi, dkk. 2007. Penelitian Tindakan Kelas. Jakarta: PT Bumi Aksara. 
Barbara L Viera dan Ferguson B. J. 2004. Bola Voli untuk Pemula. Jakarta: PT Raja Gronfindo Utama.

Budi Sutrisno. 2010. Pendidikan Jasman, Olahraga dan Kesehatan 2. Jakarta: Pusat Perbukuan Kementrian Pendidikan Nasional.

Chandra, Sodikin. 2010. Pendidikan Jasmani Olahraga dan Kesehatan. Pegadon Kendal: Kementerian Pendidikan Nasional.

Em Zul Fajri. 2008. Kamus Lengkap Bahasa Indonesia. Jakarta: Difa Publiser.

Juari, wagiono, Sukiri. 2010. Pendidikan Jasmani Olahraga dan Kesehatan. Jakarta: CV Bima Pustaka.

Mulyatiningsih, Endang. 2007. Metode Penelitian Terapan Bidang Pendidikan. Bandung: CV. Alfabeta.

Nana Sudjana. 1991. Dasar-Dasar Proses BelajarMengajar. Bandung: Sinar Baru Algensindo.

Nanang Sudrajat dan Rumawi Irawan. 2004. Pendidikan Jasmani. Jakarta: Bumi Aksara.

Nurhasanah dan Tuminto, D. 2007. Kamus Bergambar Pendidikan. Jakarta: PT. Rineka Cipta.

Nurhasnah. 2007. Pembelajaran Berbasis Masalah Untuk Meningkatkan Penguasaan Konsep, Berpikir Kritis dan Sikap Ilmiah. Tesis UPI Bandung: tidak diterbitkan.

Oemar Hamalik. 2008. Kurikulum dan Pembelajaran. Jakarta: Bumi Aksara.

Poerwadarminta, W.J.S. 2007.Kamus Umum bahasa Indonesia. Jakarta: Balai Pustaka.

Sugiyanto. 1993. Belajar Gerak.J akarta: KONI Pusat.

Suharno. H. P. 1980. Metodik Melatih Permainan Bola Volley. Yogyakarta: IKIP Yogyakarta.

Uno, Hamzah. 2010. Perencanaan Pembelajaran. Jakarta: Bumi Aksara. 
Volume 4, Nomor 1, Februari 2020 